\title{
Understanding the Characteristics of Physical Color in Human - an Article Review
}

\author{
Luh Gde Evayanti ${ }^{1}$ and Myrtati Dyah Artaria ${ }^{2}$ \\ \{eva4chiraaime@gmail.com¹ and myrtati@gmail.com² \\ Master Study Program of Basic Medical Science, Faculty of Medicine, Universitas Airlangga, Surabaya, \\ Indonesia $^{1}$ and Faculty of Social and Political Sciences, Universitas Airlangga, Surabaya, Indonesia ${ }^{2}$
}

\begin{abstract}
Evaluation of human appearance might be quite tricky in population, especially head and face region. Somatoscopy is used by Physical Anthropologists to evaluate morphological diversity in humans including the characteristics of skin color, hair, and iris. The aim is to know the variation in characteristics both between individuals and in groups or populations. Characteristics of skin color, hair, and iris have a standardized scale in evaluating it to improve the objectivity of the data.
\end{abstract}

Keywords: Hair color; iris color; skin color

\section{Introduction}

The diversity of physical morphological between humans living with one another is often based on daily observations [1]. This diversity then becomes an identity for someone to be recognized by others. In addition, the findings of human physical variation are widely used in other fields such as education, health, forensics, genetic counseling, industry etc. [2]. The method of observing physical variation in humans becomes very important considering that not all physical human morphological characteristics can be measured quantitatively [3]. These observations include the color of skin, hair, head, and iris. The characteristics of color show physical variations that cannot be measured naturally. Therefore evaluation of color characteristics tends to be subjective. In population studies it is very important to minimize subjective judgment and direct more towards objectivity.

Somatoscopy is a conventional method in physical anthropology which literally means observing the body (soma which means body, and scopy which means observation) [4]. Somatoscopy refers to qualitative assessment of both living and dead people based on visual observations of different morphological features. In addition to understanding variations between individuals, somatoscopy is important to describe the general morphology of a community group or ethnicity which is the goal of physical anthropology. Observations are usually focused on the head and face area because they are easily visible from the outside and easily identified $[1,2]$.

\section{Discussion}

\subsection{The Skin Color}


The skin is the outermost layer of the human body [5]. The skin has three layers including the epidermis, dermis, hypodermis. Skin color is determined by the melanin pigment found in the epidermis and dermis [5]. In white people the melanin pigment is only found in the stratum basale, whereas the melanin pigment of Negro is found in the stratum basale and stratum spinosum. However, there is no melanin pigment in the albino people $[4,5]$.

Skin color is a parameter with different degrees of variation based on exposure to light and heat. Some parts of the same body has a degree of color that varies depending on the extent of exposure. Skin exposed to sunlight tends to be darker than those not exposed. The part of the skin on the inner surface of the upper arm is often observed because it is slightly exposed to sunlight. Furthermore, the skin color observed compared to the standard color scale, the Luschan's skin color chart, is distinguished by 36 degrees of color on a scale of 1-36 $[2,4]$.

\begin{tabular}{|l|l|l|l||l|l|l|}
\hline & 1 & 10 & & & 19 & 28 \\
\hline & 2 & 11 & & & 20 & 29 \\
\hline & 12 & & & 21 & 30 \\
\hline & 12 & & & 22 & 31 \\
\hline 4 & 13 & & & 23 & 32 \\
\hline 5 & 14 & & & 23 & \\
\hline & 15 & & 24 & 33 \\
\hline 7 & 16 & & 25 & 34 \\
\hline 8 & 17 & & 26 & 35 \\
\hline 9 & 18 & & 27 & 36 \\
\hline
\end{tabular}

Fig. 1. Luschan's skin color chart [8].

In recent study, the spectrophotometric method can evaluate skin color. In one study comparing Luschan's skin color chart with spectrophotometry at 36 correspondents. The study concluded that evaluating skin color with Luschan's skin color chart has a significant correlation with spectrophotometry [8]. Research in the Tengger population of Argosari Village, Lumajang Regency - Indonesia, shows the average skin tone based on the Luschan's skin color chart scale between ranges 22-23 [9]. The study on 1997 described the correlation of skin with the proximity of the equatorial field. The study in more than 100 populations showed that skin reflections were lowest on the equator, then increased gradually, around $8 \%$ per 10 degrees latitude in the northern hemisphere and about $4 \%$ per 10 degrees latitude in the southern hemisphere. Italian geographer Renato Basutti, who widely reproduces "skin color maps" which broadly describe the correlation of darker skin with equatorial closeness (fig. 2) [10]. Comparison of skin color characteristics based on race can be seen in Table 1.

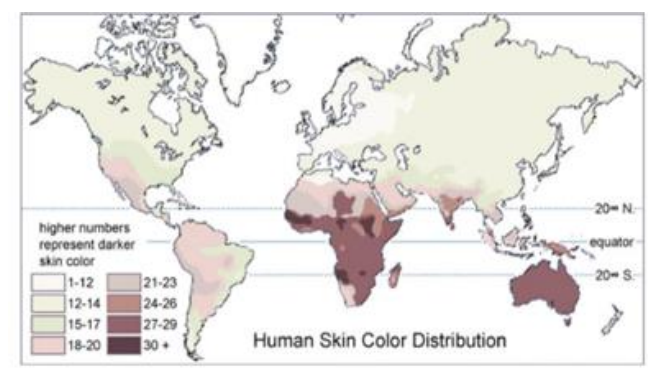

Fig. 2. Traditional map of skin color distribution by Basutti [10]. 


\subsection{The Hair Color}

The color of human hair is determined by melanin. Melanin is produced and packaged into melanosomes which are covered by membranes by melanocytes. Melanosomes are then inserted into the protein matrix related to keratin in keratinocytes during the keratinization process. This results in a relatively uniform color in the entire hair shaft. Finally, hair color is the result of the mixing ratio of two types of melanin that occurs, namely blackish eumelanin and yellowish pheomelanin [11]. Hair color evaluation in physical anthropology based on the Fischer-Saller Scale. In general it is detailed as follows [3]:

$\begin{array}{ll}\text { A } & \text { : blonde } \\ \text { B-E } & \text { : light blonde (straw) } \\ \text { F-L } & \text { : blonde } \\ \text { M-O } & : \text { dark blonde } \\ \text { P-T } & : \text { light brown to brown } \\ \text { U-Y } & : \text { dark brown to black } \\ \text { I-IV } & : \text { reddish } \\ \text { V-VI } & : \text { reddish blonde }\end{array}$

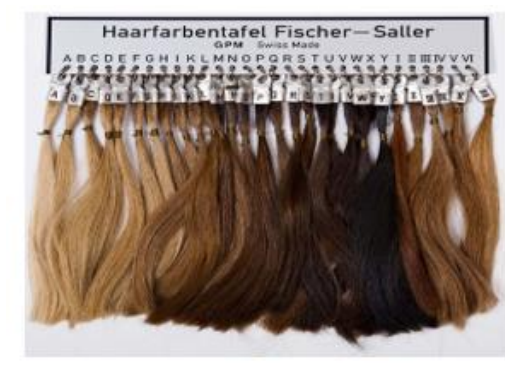

Fig. 3. Fischer-Saller Scale [12].

Indonesian hair color is generally in the category of dark brown to black (U-Y category) [3]. A study in East Nigeria of 300 female and male samples found 56.7\% black hair, 69\% dark brown iris, and $50.3 \%$ brown skin [13]. Comparison of hair color characteristics based on race can be seen in table 1 .

\subsection{The Iris Color}

The iris has a variety of colors caused by the melanin pigment in the iris epithelial layer. The color of the iris is one of the most obvious characteristics in humans. Eye colors range from the darkest shades of brown to the lightest blue (Mariana and Alina, 2015). The iris color evaluation using Martin and Schultz Eye color chart, which can be divided into [2]:

1

: dark brown

5-6 : yellow

7-8 : : greenish

9-10 : : dark gray (pigment looks uneven)

11-12 : light gray

13-15 : blue, blue gray

16 : light blue 
The last study in the Tengger population of Argosari Village, Lumajang Regency, Indonesia showing the iris color based on the Martin and Schultz scale Eye color chart is 2-3 (dark brown color) [9]. Comparison of color characteristics of iris based on race can be seen in table 1. Research on the color classification system of iris in a study using 24 eye standard photos for accuracy and can be applied to the retinal starylight study (fig. 4). The overall variation between observers is 1.46 on a scale of 0 to 25 , making it promising to be more accurate than the iris color classification system that exists in clinical situations where objective colorimetric based systems are not available [14].

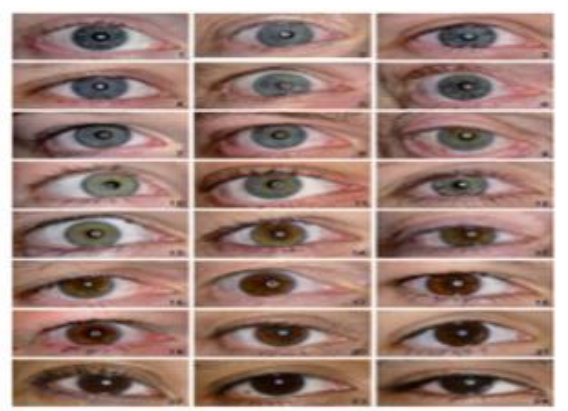

Fig. 4. Determination of references for the classification of iris pigmentation, in the order of at least (number 1) to at most (number 24) iris pigmentation which is presented sequentially based on the ranking of 4 observers [14].

One of automated techniques was the objective quantification of iris color based on spectrophotometric measurements of iris melanin. Spectrophotometric studies have shown that blue apparent irises frequently have a brown peripupilary ring and that many eyes that seem light coloured are indeed a mixture of light and dark colours [15].

Table 1. Comparison of physical color characteristics based on races.

\begin{tabular}{llll}
\hline Comparison of Human & & & \\
\hline Race & Skin Color & Hair Color & Iris Color \\
\hline $\begin{array}{l}\text { Australian Aborigine } \\
\text { and Papuan }\end{array}$ & Dark brown, black & Black & Black, dark brown \\
American Indian & Reddish-brown & Black & Black, dark brown \\
Pacific Islander & Brown & Black & Black, brown \\
Negroid & Black & Black & Black \\
Kaukasoid & White & Black, brown & Black, brown, blue, \\
& & Breen, hazel, grey \\
Dravidian & Brown to black & brown or dark & Black, dark brown \\
Asian & Yellow, yellow-brown & Black & Black \\
\hline
\end{tabular}

\section{Conclusion}

Good understanding of color characteristics on the human body would help to study about diversity of human race, genetics, social, and health state. 
Acknowledgments. Thank you to The Head of Department of Anatomy and Histology, Faculty of Medicine, Universitas Airlangga and all staffs for the support given. Luh Gde Evayanti holds a scholarship from The Faculty of Medicine, Warmadewa University.

\section{References}

[1] Yi, D, Yang, W and Li, S, Z.: Skin Spectroscopy, Encycl. Biometrics, no. October, pp. 12241229 (2009)

[2] Sharma, R, M and Sharm, R, K.: Anthropology. New Delhi: Antlantic Publishers and Distributors (1997)

[3] Glinka, J, Artaria, M, D and Koesbardiati, T.: Metode Pengukuran Manusia. Surabaya, Indonesia: Airlangga University Press (2008)

[4] Katalinic, E, B.: Analyzing The Image Of The Face, Ann. Proc. DAAAM Int., vol. 22 (1). pp. 909-910 (2011)

[5] Genetics of Skin Colour

[6] Hochschild, J, L.: EBSCOhost Discovery Service: The Skin Color Paradox and the American Racial Order., Socila Forces, vol. 86 (2). pp. 643-670 (2007)

[7] Airlangga, T, H, F, K, U.: Buku Histologi 1 sel \& Jaringan Utama. Surabaya, Indonesia: Departemen Anatomi dan Histologi Fakultas Kedokteran Universitas Airlangga (2016)

[8] Treesirichod, A, Chansakulporn, S and Wattanapan, P, P.: Correlation between Skin Color Evaluation by Skin Color Scale and Narrowband Reflectante Spectophotometer, Indian J Dhermatol, vol. 59 (4). pp. 245-259 (2014)

[9] Jati, V, D, P.: Karakteristik Fisik Secara Somatoskopi dan Adaptasi Budaya pada Populasi Masyarakat Tengger di Desa Argosari, Kecamatan Senduro, Kabupaten Lumajang, Antro Unairdot Net, vol. 4 (2). pp. 245-259 (2017)

[10] Brash, G, S.: What Controls Variation in Human Skin Color, PLoS Biol. vol. 1 (1). pp. 19-22 (2003)

[11] Birngruber, C, G and Verhoff, M, A.: The color of human hair Human Health Handbooks, in Preedy VR. (eds) Handbook Dof Hair in Health and Disease, 1st ed., Wageningen Academic Publishers (2012)

[12] Anonym, 'Fischer-Saller scale,' available at http://jorian.org/people-and-society/what-is-thepercentage-of-blond-haired-people-in-the-world\#! attachmentwp-att-89/0/, accessed on 10 Januari (2018)

[13] Ukoha, U, et al.: The prevalence and pattern of human color traitsin nigerian adults, Int J Biol Med Res, vol. 4 (2). pp. 3032-3036 (2013)

[14] Franssen, L, Coppers, J, E and van de Berg, J, T, T, P.: Grading of Iris Color with an Extended Photographic Reference Set, J Optom, vol. 1. pp. 36-40 (2008)

[15] Grigore, M and Avram, A.: Iris Colour Classification Scales - Then and Now, Rom J Ophthalmol, vol. 59 (1) pp. 29-33 (2015) 